\title{
Odczytując palimpsest miejski Na przykładzie Katowic
}

\section{Attempting to read the urban palimpsest The case of Katowice}

\begin{abstract}
Summary: The article invites the readers to approach the city itself as a text of culture. We are to read it alongside other narratives/narrations (literary, artistic, and cinematic) devoted to it. The author traces how Katowice's space has been transmuted into politically- and culturally-charged places, by distinguishing consecutive layers of the palimpsest (Polish village, building patterns of German and Polish times: the old and the new). The foregoing examples allow the author to indicate the traces of conceptions and ideologies reflected by architecture. He also includes some methodological recommendations/tips pertaining to reading the space.
\end{abstract}

Keywords: the city, space, place, text, reading, ideology, palimpsest

\section{Przestrzeń i miejsce. Uwagi wstępne}

Skojarzenia przestrzeni miasta ze ,starożytnym lub średniowiecznym rękopisem zapisanym na pergaminie, z którego został zeskrobany albo starty tekst wcześniejszy"1, czy ujmując szerzej — z ,tekstem semantycznie wielowarstwowym, w którym spoza znaczenia dosłownego prześwitują znaczenia ukryte"2, nie należą do rzadkości. Miasto XXI wieku jawi się jako ,wielość planów na-

1 T. Kostkiewiczowa: Palimpsest. W: Słownik terminów literackich. Red. J. Sławiński. Wrocław 1989, s. 337-338.

${ }^{2}$ Ibidem, s. 338. 
kładających się na siebie”3 czy wręcz „ocean znaków”4. W takim razie projekt czytania przestrzeni miasta/miejsca okazuje się zadaniem semiotycznym z wieloma niewiadomymi. Doprecyzujmy — za Yi-Fu Tuanem: „Przestrzeń jest bardziej abstrakcyjna niż miejsce. To, co na początku jest przestrzenią, staje się miejscem w miarę poznawania i nadawania wartości”’.

To rozróżnienie odniosę do procesu przekształcania przestrzeni na trzech płaszczyznach:

- zmian zachodzących $\mathrm{w}$ przestrzeni,

- kreowania przestrzeni i miejsca w tekstach kultury oraz tworzenia jej w tych tekstach,

— poznawania tak ukształtowanej struktury przez odbiorcę.

Pierwsza płaszczyzna wydaje się interesująca szczególnie w kontekście budowania przestrzeni symbolicznej miasta i nadawania mu wartości w rezultacie konstytuowania gmachów oraz ich dekonstrukcji (lub zmianie przeznaczenia), stawiania i burzenia pomników, nadawania nazw ulic i ich zmieniania. Druga płaszczyzna dotyczy odwzorowywania, parafrazowania i zniekształcania obrazu miasta w różnych tekstach kultury (opis miasta w dziele literackim, jego wizerunek malarski, sposób jego ukazania w dziele teatralnym czy filmowym), a także powstawania tekstów kultury w tej przestrzeni (jak koncert, festiwal, happening). Trzecia sfera to proces poznawania/dekodowania miejskiego palimpsestu przez odbiorcę w sytuacji choćby turystycznej (zwiedzanie indywidualne lub z przewodnikiem) czy — bardziej mnie tu interesującej — sytuacji dydaktycznej (wirtualny lub rzeczywisty spacer do szczególnych miejsc).

Zasadniczym celem opracowania jest zaprezentowanie idei odczytywania miejskiego palimpsestu na przykładzie Katowic, miasta, w którym mieszkam, uczę i którego uczę na lekcjach języka polskiego oraz edukacji regionalnej. Taki projekt ma charakter zdecydowanie interdyscyplinarny, toteż wymaga podjęcia współpracy z nauczycielami historii, wiedzy o społeczeństwie, wiedzy o kulturze (plastyki), a także — gdyby go poszerzyć — z nauczycielami geografii i przyrody. Ramy tego eseju pozwalają jedynie na zaprezentowanie kolejnych, architektonicznych warstw miejskiej zabudowy, na przywołanie kilku różnych tekstów kultury odniesionych do określonego miejsca w mieście oraz na zarys ich analizy. Garść metodycznych wskazówek do szkolnej lektury miasta zaprezentuję w końcowej części artykułu.

${ }^{3}$ L. Sobkiewicz: Waltera Benjamina filozofia ulicy. W: Przestrzeń, filozofia i architektura. Red. E. Rewers. Poznań 1999, s. 149.

4 A. Lasiewicz-Sych: Obraz dialektyczny ,,nowej” architektury. W: Przestrzeń..., s. 153.

${ }^{5}$ Yi-Fu Tuan: Przestrzeń i miejsce. Tłum. A. Morawińska. Warszawa 1987, s. 16. 


\section{Miasto}

Traktowanie miasta jako palimpsestu i jego wielowarstwowe odkrywanie okazały się ważną strategią po przełomie roku 1989 — spod szarej socjalistycznej fasady wydobywano głębiej ukryte warstwy. Proces ten wywarł silny wpływ na literaturę małych ojczyzn ${ }^{6}$. Tak choćby postrzegano Gdańsk - jako „miasto-palimpsest, przemieszanych i poukrywanych warstw kulturowych, cywilizacyjno-materialnych, swoisty stop wielokulturowy przezierających śladów, fragmentów, wygrzebywany zza odsłaniających się nawarstwień elementów, które czytane są różnymi językami”7.

Katowice to przestrzeń, która wyłania się z mroku dziejów jako XVI-wieczna polskojęzyczna wioska rozwijająca się przy Kuźnicy Boguckiej, w XIX wieku staje się miastem zbudowanym przez Niemców i Żydów, a od prawie stu lat jest stolicą polskiego Górnego Śląska — również wartą poznania. Jej odkrywanie to także wyzwanie, czy raczej wezwanie do lektury, do analizowania „rozmaitości pisma, jakim zostały zapisane" Katowice ${ }^{8}$. To wezwanie powinno wynikać z troski o budowanie tożsamości miejsca oraz z odpowiedzialności za tworzenie nowej wspólnoty pamięci.

Skoncentruję się na opisie trzech placów znajdujących się na terenie dzisiejszych Katowic. Są to: śródmiejski rynek, plac Sejmu Śląskiego oraz nikiszowiecki plac Wyzwolenia. Pod wieloma względami wszystkie te miejsca można określić jako wielowarstwowe. Pozostałe fragmenty zabudowy lub zachowane wizerunki placów pozwalają prześledzić procesy historyczne przekształcające miasto w duchu ideologii państwa, które danym obszarem zarządzało, oraz towarzyszące tym procesom kulturowe formy wyrazu najwyraźniej zachowane w architekturze budowli.

Plany tych miejsc wskazują, że Katowice zostały miastem w wielu miejscach starannie wykreślonym. Nie mam tu bynajmniej na myśli niechlubnego okresu stalinogrodzkiego, zostały bowiem miastem ,powstałym na podstawie koncepcji inżynierskiej”".

${ }^{6}$ Zob. E. Dutka: „Za, a nawet przeciw”, czyli parę uwag i pytań o palimpsestowość miejsc i przestrzeni. W: Palimpsest. Miejsca i przestrzenie. Red. A. Gomóła, A. Szawerna-Dyrszka. Katowice 2018, s. 20.

${ }^{7}$ A. Bagłajewski: Miasto - palimpsest. W: Miejsce rzeczywiste, miejsce wyobrażone. Studia nad kategoria miejsca w przestrzeni kultury. Red. M. Kitowska-Łysiak, E. Wolicka. Lublin 1999, s. 317.

${ }^{8}$ H. Waniek: Katowice blues. Katowice 2010, s. 26.

9 I. Kozina: Chaos i uporzadkowanie. Dylematy architektoniczne na przemystowym Górnym Ślasku w latach 1763-1955. Katowice 2005, s. 247. 


\section{Rynek}

Heinrich Nottebohm, dworski inspektor budowlany, który wytyczył plan Rynku (pierwotnie Markt, później Ring), dojrzał go w miejscu, gdzie „prastara błotnista z zachodu na wschód prowadząca tzw. polska droga"10 (obecnie ulice 3 Maja i Warszawska) krzyżowała się z drogą północ-południe, a przy skrzyżowaniu stała żydowska karczma. Z braku realistycznego szkicu musimy się zadowolić landszaftem niemieckiego pejzażysty Ernsta Knippla. To mógłby być — gdyby zgodzić się z Wojciechem J. Bursztą twierdzącym, że deskrypcja wsi i małego miasteczka była opisem „samym w sobie”, opisem „samozrozumiałym"11 — tekst pierwotny naszej lektury Katowic.

Pozostałością po tej najstarszej warstwie jest figurka św. Jana. Stała na skrzyżowaniu drogi z Chorzowa i Siemianowic (dzisiejsza aleja Korfantego i ulica Świętego Jana) oraz traktu z Pszczyny i Mikołowa (ulice Młyńska, Staromiejska i Starowiejska). Po dziesięciu latach od powstania miasta, kiedy ulice brukowano, władze zdecydowały, że figurka utrudnia ruch i usunęły ją z tego miejsca. Nie została jednak zniszczona, lecz przeniesiona do zagrody Mikołaja Maczugi w Brynowie. Georg Hoffmann, nauczyciel Staatliches Gymnasium, traktuje to wydarzenie w swojej Historii miasta Katowice w sposób symboliczny: „Zniknął jedyny symbol miejscowości Katowice — statua św. Jana Nepomucena"12. Taka — chciałoby się dodać - wiejska statua wolności polskich chłopów.

Kolejne warstwy palimpsestu tworzą: XIX-wieczna neobarokowa kamienica narożna między ulicami Pocztową a Młyńską oraz późniejszy gmach teatru — niemiecka warstwa miejska, a także miejska warstwa polska — sklepy z okresu PRL-u: Skarbek (wcześniej Arenda) i Zenit (w miejscu hotelu Welt). Najnowsza warstwa (po 1989 roku) to między innymi podwyższona platforma, tzw. plac Kwiatowy, nowa siedziba urzędu miasta (dawniej Dom Prasy). Brak na Rynku wyraźnych pozostałości z okresu międzywojennego — śladem ingerencji $\mathrm{w}$ tamtym czasie jest między innymi wyburzenie jednego $\mathrm{z}$ budynków i poszerzenie drogi na północ — dzisiejszej alei Korfantego.

Na pocztówkach z czasów niemieckich często widoczna bywa z rynku kopuła wielkiej synagogi w stylu renesansowym z elementami średniowiecznymi. Ów synkretyczny styl był realizacją myśli Edwina Opplera, akcentującego w tej architektonicznej formie wyrazu wspólnotę losu Żydów i Niemców ${ }^{13}$. Świątynia

${ }^{10}$ W. Nałęcz-Gostomski: Dzieje i rozwój Wielkich Katowic jako ośrodka przemystu i stolicy autonomicznego województwa śląskiego. Katowice 1926, s. 78.

${ }_{11}$ W.J. Burszta: Miasto i wieś - opozycja mitycznych nostalgii. W: Pisanie miasta - czytanie miasta. Red. A. Zeidler-Januszewska. Poznań 1997, s. 105.

${ }_{12}$ G. Hoffmann: Historia miasta Katowice. Tłum. D. Makselon, M. Skop. Katowice 2003, s. 145.

${ }^{13}$ Za: I. Kozina: Chaos i uporzadkowanie..., s. 64. 
została spalona we wrześniu 1939 roku. Wraz z budynkiem gimnazjum (dziś budynek III Liceum Ogólnokształcącego im. Adama Mickiewicza) oraz gmachem miejskiej łaźni tworzyły one neogotycki kwartał miasta.

Na początku lat pięćdziesiątych XX wieku architekci Miastoprojektu opracowali nową koncepcję przestrzenną śródmieścia:

Centrum socjalistycznego Stalinogrodu skupiać się będzie wokół znacznie poszerzonego rynku. Ostanie się przy nim tylko obecny gmach teatru, reszta budynków, stanowiących dziedzictwo epoki kapitalistycznej, ustąpi miejsca wielkim, nowoczesnym budynkom administracyjnym, handlowym i kulturalnym ${ }^{14}$.

Niezwykłym pomysłem tego czasu był projekt cyrku wolnostojącego, który miał się znaleźć w okolicy Rynku. Plan Hipolita Rutkowskiego nawiązywał do monumentalnych projektów XVIII-wiecznych planistów rewolucjonistów ${ }^{15}$.

„Świątynny charakter »centrum «"16 przejawiał się w reprezentacyjnych miejscach $\mathrm{w}$ różnorodny sposób - dla rynku taką świątynią jest ratusz (to funkcja pragmatyczna każdego rynku) — był on w miejscu, gdzie dziś znajduje się teatr, potem mniej więcej tam, gdzie znajduje się narożna kamienica między ulicami Pocztową a Młyńską. Świątynny charakter Rynku od przeszło stu lat symbolizuje jednak gmach teatru. Wyraźnym gestem zatarcia wcześniejszego tekstu było usunięcie z tympanonu teatru napisu: Deutschem Wort - deutscher Art („Niemieckiemu słowu — niemieckiej sztuce”) i skucie części płaskorzeźb odwołujących do Pierścienia Nibelungów.

Większość „usunięć” zaczęła się od roku 1945 — od spalenia części rynku przez Armię Czerwoną i tworzenia ,ułudy nowego, socjalistycznego świata”17, którego namiastkę dawały wspomniane: Zenit i Skarbek. Faktycznie nowoczesny okazał się budynek wzniesiony w latach siedemdziesiątych, symbol kosmicznej ery — hala widowiskowa Spodek, na którą roztacza się widok z północnej strony Rynku. W tym miejscu katastroficzną wizję zagłady Katowic snuł Feliks Netz. W jego fabule ożywają kamienne dinozaury z nieodległej kotliny w Parku Śląskim i atakują Śródmieście, także Spodek:

Z czasem, nie bez trudu, udało mi się ustalić, że: szesnastka, zjeżdżająca z góry ku Rondu, przejechała rutynowo pod szarym brzuszyskiem dino-

${ }^{14}$ Ibidem, s. 205.

15 Zob. H. Rutkowski: Studium gmachu cyrku wolnostojącego w Stalinogrodzie. Opis projektu. „Architektura” 1955, nr 7, s. 206.

${ }^{16}$ T. Sławek: Akro/nekro/polis: wyobrażenia miejskiej przestrzeni. W: Pisanie miasta..., s. 23.

17 A. Borowik: Nowe Katowice. Warszawa 2019, s. 443. 
zaura, nie zatrzymując się; przecież jechałem tym tramwajem i podobnie jak motorniczy (to już moje domniemanie) nie przyjąłem do (ś)wiadomości, iż to, co przed chwilą przyciemniło obraz za szybą okienną [...], to nie wiszące nisko, ciemne chmury, zapowiadające deszcz, lecz cień dinozaura $^{18}$.

Na katowickim Rynku toczy się także akcja Zawróconego Kazimierza Kutza. W jednej ze scen główny bohater Tomasz Siwek, którego gra Zbigniew Zamachowski, bierze udział w demonstracji zwolenników Solidarności formalnie jako agent władzy, ale faktycznie — jako protestujący: porwany zapałem tłumu w patriotycznym uniesieniu śpiewa Boże, coś Polske. Śpiewa na tle pomnika ukazującego bohaterów rozstrzelanych przy ulicy Zamkowej (dzisiejsza aleja Wojciecha Korfantego) we wrześniu 1939 roku. Może bardziej na miejscu byłaby tu Bogurodzica. Szczególnie jeśli weźmiemy pod uwagę, że dokładnie w tej części Rynku, zwanej placem Obrońców Katowic, od XIV wieku funkcjonowała część Kuźnicy Boguckiej, a budynki kuźnicze znajdowały się w miejscu obecnego Separatora.

\section{Plac Sejmu Śląskiego}

Początkiem przekształcania przestrzeni w polskie miejsce (Rynek mimo wprowadzenia rodzimych akcentów, lecz niewyburzania zabudowań w okresie międzywojennym, nie dał się nie czytać jako miejsce niemieckie) była decyzja o zagospodarowaniu części miasta i stworzeniu konkurencyjnej przestrzeni reprezentacyjnej. W czasach niemieckich przy dzisiejszej ulicy Jagiellońskiej wybudowano jedynie budynki dydaktyczne: „Przy ulicy Prinz-Heinrichstrasse powstała miejska szkoła średnia (Oberrealschule) oraz Szkoła im. Księcia Henryka (Prinz-Heinrich-Schule)"'19.

Od 1922 roku teren ten staje się zatem miejscem polskim: ulica księcia Heinricha zostaje ulicą Jagiellońską, niemieckie szkoły — zastąpione polskimi, a naprzeciw zaczyna się budowa budynku Urzędu Wojewódzkiego i Sejmu Śląskiego. Taki obiekt powstać musiał — Katowice awansowały do roli stolicy regionu. Kiedy w 1922 roku ogłoszono konkurs na projekt budynku, zaznaczono w jego regulaminie wyraźnie: „Styl gotycki wyklucza się”. Powstał zatem

${ }^{18}$ F. Netz: Dysharmonia caelestis. Katowice-Warszawa 2004, s. 184.

${ }^{19}$ L. Dame: Jak Katowice stały się miastem. Tłum. N. Nowara-Matusik. W: Katowice oczami Niemców i Polaków. T. 1. Red. G.B. Szewczyk. Katowice 2017, s. 87. 
budynek w konwencji zmodernizowanego klasycyzmu — ,uniwersalizm form klasycystycznych powodował, że były one często w różnych częściach Europy zawłaszczone jako architektura o wyrazie narodowym"20. Faktycznie - forma budynku różni się wyraźnie od neogotyckich budowli, choć przypomina przecież neoklasycyzm gmachu Melpomeny — wówczas jednak taką architekturę odbierano jako „mocną odpowiedź na styl germański”"21. Tę polskość podkreślały płaskorzeźby Jana Raszki, zatytułowane Alegoria województwa śląskiego, przedstawiające między innymi Polonię na tronie z godłem i włócznią przypominającą Atenę, oraz znicze nawiązujące do ognia westalek — zapewne odpowiedź na teatralne płaskorzeźby z Nibelungami.

To zdumiewające, że plac Sejmu Śląskiego — ,niepodważalny pomnik polskości Katowic i symbol autonomicznego województwa w dwudziestoleciu międzywojennym", już w rok po upamiętnieniu bohaterstwa śląskich powstańców, staje się areną faszystowskiego wiecu, a po upływie kolejnych kilku lat jest theatrum komunistycznym.

W tradycyjnym kontekście okolicę przedstawił w swym filmie Szczęście świata Michał Rosa: budynek urzędu jest twierdzą, która nie dostanie się w ręce wroga - tak trzeba odczytywać scenę demonstracji z sierpnia 1939 roku. Głównym miejscem akcji jest jednak znajdujący się gdzieś niedaleko niezwykły dom, pokazujący wieloetniczną strukturę przedwojennego Śląska (na kolejnych piętrach mieszkają tu: rodzina śląska, niemiecka, samotny polski miłośnik przyrody i wabiąca wszystkich swoim czarem Żydówka - Szczęście świata).

Inaczej gmach urzędu i okolice ,naszą rzeczywistość” [podkr. - K.W.] zapamiętał artysta zwiedzający Śląsk w latach trzydziestych:

Gmach województwa w Katowicach jest jednym z najpotężniejszych gmachów, jakie kiedykolwiek widziałem. Nie jest on ładny i trochę przebrzmiały w swoim architektonicznym wyrazie. [...] W swej granitowej okazałości ma jakiś petersburski charakter. „Zimnij Dworiec” naszej rzeczywistości stanowi moment najcharakterystyczniejszy śląskiego pejzażu ${ }^{22}$.

„Pałac Zimowy”, a dokładniej: Grudniowy, wyczarowano tu nieomal między potężnymi gmachami władz wojewódzkiej i partyjnej. Kilkadziesiąt lat później rozpoczęto budowę Centrum Kształcenia Ideowo-Wychowawczego Kadr Robotniczych (dziś Katowice Miasto Ogrodów - Instytucja Kultury im. Krystyny Bochenek). Po 1945 roku przestrzeń zmieniła symbole (między innymi nazwę na plac Dzierżyńskiego!), choć nie zmieniła przeznaczenia to także dziś najbardziej polityczny plac miasta.

\footnotetext{
${ }^{20}$ I. Kozina: Chaos i uporzadkowanie..., s. 102.

${ }^{21}$ Ibidem, s. 104.

22 J. Iwaszkiewicz: Podróże do Polski. Warszawa 1987, s. 124.
} 
O ile przedwojenny plac Powstańców i gmach Urzędu Wojewódzkiego były polską odpowiedzią na Rynek, którego wyraźnie spolonizować się nie udało, o tyle budowa nowej partyjnej siedziby była rozgrywką wewnętrzną tamtej władzy. Tak to opisuje narrator Cysorza:

Idea jego pałacu [Grudnia - K.W.] powoli spełniała się. A tak po prawdzie, to już się spełniła. Przecież chodziło głównie o tę salę spędową, gdzie mógłby odbierać hołdy, nie będąc posądzany, że naśladuje Gierka w Spodku. To, że trzy czwarte budynku było wciąż w budowie, nie miało żadnego znaczenia. Obiekt stał już na zewnątrz w jako takiej krasie. Główna sala — w morderczym tempie wykańczana na wojewódzką konferencję — już służyła swojemu celowi²3.

Rozgrywką polityczną znacznie odłożoną w czasie było usytuowanie pomników dwóch antagonistów: Wojciecha Korfantego i Józefa Piłsudskiego. Postacie z pomników na siebie nie patrzą — dzielą ich mury gmachu województwa. Korfanty zajął miejsce na cokole przeznaczonym dla Marszałka, jego z kolei pomnik wylądował na cokole przeznaczonym dla komunistycznego bohatera. Budynek Okręgowej Rady Związków Zawodowych, który dziś stoi za pomnikiem, wybudowano w latach 1952 - 1955. Na osi budowli planowano pierwotnie pomnik komunistyczny ${ }^{24}$, dziś króluje tu Marszałek.

Czasy odrzucania stalinowskiego reżimu w najgorszym stalinogrodzkim momencie dziejów miasta tak zapisały się w pamięci bohaterów Dysharmonia caelestis:

— Towarzyszu Ksawery [...] jest sugestia, żebyście się udali na plac Dzierżyńskiego, gdzie cały czas wali (tak powiedział: wali!) tłum, i spróbowali go wywabić (tak powiedział: wywabić) sprzed komitetu i skierować do nas, przed rozgłośnię [...] dopiero późnym wieczorem, o godzinie 22.00, przerwano program i przeczytałem komunikat, że uchwałą Rady Państwa czy Sejmu, już dokładnie nie pamiętam, Katowice powracają do swojej historycznej nazwy. I wtedy powiedziałem po raz pierwszy: „Tu Radio Katowice" ${ }^{25}$.

Zamknięciem tej sceny jest najbardziej palimpsestowy fragment historii miasta: „Miasto, w którym żył od niedawna, zrzucało z ramion szynel nienawistnej nazwy i on razem z tysiącem szabel bezlitośnie go deptał"26.

\footnotetext{
${ }^{23}$ M. Smolorz [S. Szulecki]: Cysorz. Katowice 1990, s. 89.

${ }^{24}$ I. Kozina: Chaos i uporzadkowanie..., s. 214.

${ }^{25}$ F. Netz: Dysharmonia..., s. 96-97.

${ }^{26}$ Ibidem, s. 97.
} 


\section{Plac Wyzwolenia}

Główny plac Nikiszowca, jak również całe osiedle robotnicze dziś znajdujące się we wschodniej części Katowic powstały i tym razem przy stole kreślarskim. Autorami projektu byli stryjeczni bracia Emil i Georg Zillmannowie, natomiast pomysłodawcą wybudowania dwóch osiedli (Giszowiec i Nikiszowiec) wywiedzionych z lokalnych tradycji okazał się tajny radca górniczy Anton Uthemann.

Oddajmy głos historykowi sztuki:

Architektura bloków nawiązywała do estetyki „familoka”. Wszystkie były tej samej wysokości, dwu- lub pięcioosiowe, o elewacjach wyłożonych cegłą licówką. Ich wyraz estetyczny różnicowały płaskie wykusze owalne, prostokątne, trapezoidalne, ozdobione pasami cegły układającej się w geometryczne wzory. Różne kształty miały też bramy i obramienia drzwi. Wszystkie te elementy ożywiały wyraz architektoniczny budowli ${ }^{27}$.

Początkowo centralnym punktem górniczego miasteczka z czerwonej cegły, czymś „,na kształt świątyni”28, jest budynek zarządu kopalni Giesche przy wieży szybu Carmer (,zagrał” w finale Perly w koronie), która góruje nad przestrzenią. Znajduje się on jednak poza obrębem Rynku. Kiedy stanie przy nim — już zaprojektowany — kościół Świętej Anny, wtedy właśnie Kirchplatz (plac Kościelny) stanie się axis mundi tego małego kosmosu. Kościół wyróżnia się na tle zabudowy masywną bryłą, neobarokowymi kształtami i hełmowym dachem — różnym na przykład od neogotyckiej wieży szybu, ma bowiem przypominać najważniejsze śląskie sanktuarium na Górze Świętej Anny. Co ciekawe, pomysł takiego wyróżnienia wychodzi od Uthemanna: „Zauważę tylko, że wybrany styl — polski barok jezuicki — jest, wedle mojej opinii, zarówno ze względu na historię, jak i krajobraz, bardziej stosowny w tej okolicy niż gotyk" 29 .

Tak tę przestrzeń postrzega komisarz Drwęcki, główny bohater Ślaskiego dziękczynienia, współczesnego kryminału z akcją osadzoną w międzywojniu:

Pierwsze wrażenie było takie, jakby wjechali w ceglany labirynt. [...] $\mathrm{W}$ centrum szeregi bram układały się $\mathrm{w}$ arkadowe mosty unoszące zawieszone nad ziemią ciągi okien. [...] Miało to swój urok, intrygowało, lecz wyglądało obco. Rzeczywiście czuć tu było Zachód, bo bardzo podobne

${ }^{27}$ B. Szczypka-Gwiazda: Urbanistyka i architektura drugiej połowy XIX wieku i poczatku XX stulecia. W: Sztuka Górnego Ślaska. Red. E. Chojecka. Katowice 2004, s. 202.

${ }_{28}^{28}$ M. Szejnert: Czarny ogród. Kraków 2007, s. 44.

${ }^{29}$ Ibidem, s. 75. 
robotnicze miasteczka można było znaleźć w Anglii i Ameryce. Klimat zachodniej cywilizacji emanował z każdej cegły ${ }^{30}$.

Wiele uroczych zakątków tych osiedli rozsławił Kutz w filmowej trylogii. W zbiorowej podświadomości zachowały się przede wszystkim sceny batalistyczne z II powstania śląskiego filmowane na ulicach (szturm na pocztę) i centralnym placu Nikisza (pogrzeb bohaterów, egzekucja powstańców).

Nikiszowiec to ulubiony krajobraz śląskich filmowców: tu kręcili swoje filmy Janusz Kidawa, Maciej Pieprzyca czy Lech Majewski. Ostatni z wymienionych ukazał w swoim dziele losy niezwykłych artystów nieprofesjonalnych, zrzeszonych w Grupie Janowskiej. Obrazy Teofila Ociepki, Ewalda Gawlika czy Erwina Sówki to niezwykły palimpsest ukazujący przenikanie się świata magii i świata rzeczywistego. Najbardziej charakterystyczna pod tym względem jest twórczość Lecha Majewskiego. Unikatowość Sówki to jego swoisty synkretyzm — łączy on w planie obrazu „odmienne kulturowo elementy ikonograficzne"31. Czerpie inspiracje z Mahabharaty i Bhagawadgity. Na jego obrazach sąsiadują z sobą bogini Isztar i Święta Barbara, Hare Kriszna i Skarbnik.

Ten synkretyczny układ motywów został przeniesiony do spektaklu Skazany na bluesa wyreżyserowanego przez Arkadiusza Jakubika, a wystawionego w Teatrze Śląskim. Spektakl poświęcony charyzmatycznemu Ryszardowi Riedlowi, wokaliście zespołu Dżem, nawiązuje w swojej warstwie scenograficznej do płócien mistrza Sówki - scenę zaludniają postacie, bożki, boginie, święci i świątki... Temat przedstawienia teatralnego jako dzieła wielowarstwowego wymaga osobnego opracowania, szczególnie w kontekście cyklu przedstawień, który dyrektor sceny Robert Talarczyk zamknął tytułem Śląsk święty, Śląsk przeklęty, a na które składają się tak ciekawe tytuły, jak: Piąta strona świata, Drach czy Czarny ogród.

\section{Podsumowanie z metodyczną zachętą}

Miasto staje się palimpsestem architektonicznym w trakcie swego rozwoju. Najczęściej dzieje się to w rytm dziejowych przemian - powstają kolejne budynki w miejsce wyburzanych, stare zmieniają swoje przeznaczenie, nowoczesne nierzadko szybko się starzeją. Style architektoniczne wynikają z ducha epoki i wyznawanej w niej ideologii. Trudno nie zgodzić się z opinią Wańka:

${ }^{30}$ K.T. Lew andow ski: Śląskie dziękczynienie. Wrocław 2009, s. 46.

${ }^{31}$ M. Fiderkiewicz: Zaszyfrowany wszechświat malarstwa Erwina Sówki. Katowice 2016, s. 117. 
W razie potrzeby (po 1922) wyburzano istniejące budowle, aby zyskać miejsce. Miasto stało się przestrzenią budowlanej przepychanki, bezceremonialnej wobec już istniejącej tradycji [...]. I nie był to dialog różnych smaków czy pomysłów na gospodarowanie przestrzenią Katowic, ale raczej zapiekłe swary, w których zawsze jedno chciało być górą ${ }^{32}$.

Zastanawiające, że podobne wrażenia zanotował Bruno Arndt, katowiczanin, absolwent Oberrealschule przy dzisiejszej ulicy Jagiellońskiej, w swojej noweli Missa solemnis:

Nasze miasto stało się jednym z pierwszych miast przemysłowych i wraz z tym rozwojem narodził się w nim duch wrogi wszelkiemu pięknu, duch materializmu, pazernego i nastawionego na zysk amerykanizmu [...] ja chcę być stróżem piękna na tym kawałku ziemi, przewodnikiem dla człowieka poszukującego czegoś więcej ${ }^{33}$.

Wydawałoby się, że wielkie budowle czy monumentalne gmachy są na wieki wpisane w przestrzeń miasta, że trwale budują jego tożsamość, nie zawsze jednak tak bywa... Szczególnie w przypadku Katowic, czy szerzej nawet: wielu śląskich miast oraz ich mieszkańców ${ }^{34}$. Katowice wydają się miastem niepowstrzymanej awangardy — bo takie miano otrzymały budynki: drapacz chmur przy ulicy Żwirki i Wigury, Zenit, Skarbek, „Pałac Grudnia” czy Spodek. Tę zmieniającą się rzeczywistość zatrzymują artyści, którzy „ulegają czasowi, ale nie chcą go uznać". Przestrzeń miasta zatrzymują w swych pomnikach, obrazach, książkach, zdjęciach, spektaklach czy filmach.

Kiedy śledzi się historię trzech katowickich placów, można dojść do wniosku, że najlepiej próbę czasu przetrwała ta ostatnia zabudowa. Czy nie dlatego, że najmniej ulegała dyktatowi wielkich narracji? Że umiejętnie łączyła lokalność i uniwersalność? Że przetrwała praktycznie w niezmienionym kształcie?

A jak czytanie miasta włączyć do procesu dydaktycznego? Zadaniem nauczyciela polonisty jest przede wszystkim towarzyszenie uczniowi w lekturze tekstu literackiego. Ten ostatni coraz rzadziej zagląda między okładki dzieła. Tymczasem otwarty tekst, z którym obcuje na co dzień, często pozostaje przezeń nieodczytany lub wręcz ignorowany.

Można ucznia nakłonić, zaczynając od analizy fotografii, obrazu, wiersza... Analizę wybranych przeze mnie przykładów warto zaplanować jako odrębne jednostki lekcyjne. Na osobne zajęcia zasługuje analiza rzeźby Świętego Jana

${ }^{32}$ H. Waniek: Wstęp. W: Ulice i place Katowic. Red. G. Grzegorek. Katowice 2015.

${ }_{33}$ Cyt. za: F. Lubrich: Katowickie Towarzystwo Śpiewacze im. Oskara Meistera. Tłum. M. Blidy. W: Katowice oczami Niemców i Polaków..., s. 149.

${ }^{34}$ Palimpsestem był dla Ksawerego Pruszyńskiego sam Ślązak, którego odkrywał on po 1922 roku. Zob. K. Pruszyński: Węgiel i człowiek. „Wiadomości Literackie” 1936, nr 48. 
— ten wizerunek jest na tyle niejednoznaczny, że trudno ustalić, którego świętego wyobraża - Jana Chrzciciela, Jana Apostoła czy niezwykle na Śląsku popularnego Jana Nepomucena. Ciekawiej wypadnie konfrontacja tego wizerunku z innymi, szczególnie z figurką Świętego Jana znajdującą się przed kościołem Mariackim czy przed sanktuarium bogucickim ${ }^{35}$.

Nieodzowne okażą się fotografie wybranego miejsca w mieście. Jakże pouczające, szczególnie z historycznego punktu widzenia, będzie zestawienie fotografii z placu Sejmu Śląskiego przedstawiające kolejno: mszę polową w intencji powstańców śląskich (1938), „,powitanie” niemieckiego wojska (październik 1939), wiec poparcia komunistycznej władzy (1 maja 1951) czy jedną z manifestacji po 1989 roku $^{36}$.

Wdzięcznym materiałem do analizy ikonograficzno-ikonologicznej ${ }^{37}$ są obrazy twórców Grupy Janowskiej znajdujące się w zbiorach śląskich muzeów, przede wszystkim w Muzeum Śląskim oraz Muzeum Historii Katowic. Odbiór tych obrazów należy poprzedzić fragmentem eseju historyka sztuki ${ }^{38}$ albo fragmentem filmu Lecha Majewskiego Angelus. Główną część zajęć warto poświęcić wybranemu obrazowi artysty z tego kręgu. Intrygująca wydaje się szczególnie analiza Trzeciej warstwy Erwina Sówki dokonana przez Marię Fiderkiewicz ${ }^{39}$.

Tradycyjną formę pracy na lekcji stanowi analiza „tradycyjnego" tekstu związanego z miastem. W przypadku Katowic można wskazać i Officina ferraria Walentego Roździeńskiego, i dzieła autorów już przywołanych, głównie prozę i poezję Feliksa Netza (Śródmieście), Cysorza Michała Smolorza (Śródmieście), Piąta stronę świata Kazimierza Kutza (Szopienice), Śląskie dziękczynienie Konrada T. Lewandowskiego i Czarny ogród Małgorzaty Szejnert (Nikiszowiec i Giszowiec). Omówienie wybranych fragmentów da się umieścić w kontekście historycznoliterackim (na przykład: odczytanie wiersza Feliksa Netza poświęconego górnikom z kopalni Wujek w kontekście poezji stanu wojennego ${ }^{40}$ ) czy też w konfrontacji z innym tekstem kultury (powieść Kutza a album rapera Miuosha) ${ }^{41}$.

Realizacja wszystkich omówionych propozycji najlepsze efekty przyniesie w czasie wycieczki dydaktycznej przeprowadzanej w wybranym punkcie

${ }^{35}$ Przydatna w przygotowaniu zajęć będzie na pewno następująca pozycja: J. Marecki, L. Rotter: Jak czytać wizerunki świętych. Kraków 2013.

${ }^{36}$ Bogaty materiał wraz ze szczegółowymi opisami znajduje się między innymi w cytowanej już publikacji: Ulice i place Katowic...

${ }^{37}$ E. Panofsky: Studia z historii sztuki. Wybrał, oprac. i posłowiem opatrzył J. Białostocki. Warszawa 1971.

${ }^{38}$ Zob. np. S.A. Wisłocki: Janowscy ,kapłani wiedzy tajemnej”. Okultyści, wizjonerzy i mistrzowie matej ojczyzny. Katowice 2013.

${ }^{39}$ M. Fiderkiewicz: Zaszyfrowany wszechświat malarstwa Erwina Sówki..., s. 118 i nast.

${ }^{40}$ F. Netz: W blasku ich śmierci. W: Idem: Trzy dni nieśmiertelności. Mikołów 2009, s. $69-70$.

${ }^{41}$ Miuosh: Piąta strona świata. [Płyta CD]. Fandango Records 2011. 
miasta. Na samym placu Wyzwolenia przeprowadzić można co najmniej dwie lekcje: zajęcia poświęcone janowskim obrazom oraz lekcje na temat filmów Kazimierza Kutza; w tym drugim przypadku konieczne jest pokazanie wcześniejszych fragmentów Soli ziemi czarnej i Perly w koronie.

Wartą rozważenia propozycję stanowi przygotowanie wraz z innym nauczycielem, na przykład z historykiem, wycieczki interdyscyplinarnej. O tym, jak przygotować się do takiego przedsięwzięcia, pisała jeszcze w zeszłym stuleciu pionierka śląskiej edukacji regionalnej:

Uczniowie powinni mieć mapy i plany miasta, by doskonalić umiejętność posługiwania się nimi i mieć możliwość porównania opisu z mapy czy planu z rzeczywistością. Informacje zdobyte w trakcie wycieczki trzeba w interesujący sposób utrwalić i włączyć w ich system wiedzy. Wycieczka powinna oddziaływać na wyobraźnię, rozwijać zainteresowania historyczne, kształtować refleksyjny stosunek wobec przeszłości i teraźniejszości ${ }^{42}$.

Dziś dużym ułatwieniem w organizowaniu takich wyjść poza przestrzeń szkoły są gotowe aplikacje, z których uczestnicy mogą korzystać w swoich telefonach komórkowych.

Jeszcze inną propozycją dydaktyczną, chyba najczęściej w praktyce szkolnej podejmowaną, jest uczestnictwo w wydarzeniu społeczno-kulturalnym organizowanym na terenie miasta. Szczególnie inspirujący może być wybór takiego przedsięwzięcia, które zmienia dobrze znaną nam przestrzeń (na przykład w czasie projekcji multimedialnych na fasadach budynków).

Takie propozycje można by mnożyć w nieskończoność, ponieważ lektura miasta bywa niemal zawsze inna. Każdorazowy jego ogląd daje inny obraz miasto przecież przeistacza się nieustannie. Bo czyż dziś nie jest tak, jak w ujęciu Tadeusza Sławka:

W ten sposób miasto ponowoczesne (by posłużyć się pięknym określeniem Zygmunta Baumana) jest zawsze ,re-konstruowane”, jawiąc się w jednym miejscu, nigdy nie umiejscawia się tam na dobre, konstruuje kolejne „,entra”, lecz struktury te są zawsze już „re-konstruowane”, przeniesione z innych miejsc miejscami nie (do końca, nie na dobre) umiejscowionymi ${ }^{43}$.

${ }^{42}$ K. Dyba: Historia na ulicach Katowic. Propozycje zajęć z edukacji regionalnej. Katowice 1998, s. 5.

${ }^{43}$ T. Sławek: Akro/nekro/polis..., s. 35. 


\section{Bibliografia}

Bagłajewski A.: Miasto - palimpsest. W: Miejsce rzeczywiste, miejsce wyobrażone. Studia nad kategoria miejsca w przestrzeni kultury. Red. M. Kitowska-Łysiak, E. Wolicka. Lublin 1999.

Borowik A.: Nowe Katowice. Warszawa 2019.

Burszta W.J.: Miasto i wieś - opozycja mitycznych nostalgii. W: Pisanie miasta - czytanie miasta. Red. A. Zeidler-Januszewska. Poznań 1997.

Dame L.: Jak Katowice staty się miastem. Tłum. N. Nowara-Matusik. W: Katowice oczami Niemców i Polaków. T. 1. Red. G.B. Szewczyk. Katowice 2017.

Dutka E.: „Za, a nawet przeciw”, czyli parę uwag i pytań o palimpsestowość miejsc i przestrzeni W: Palimpsest. Miejsca i przestrzenie. Red. A. Gomóła, A. Szawerna-Dyrszka. Katowice 2018.

Dy ba K.: Historia na ulicach Katowic. Propozycje zajęć z edukacji regionalnej. Katowice 1998.

Fiderkiewicz M.: Zaszyfrowany wszechświat malarstwa Erwina Sówki. Katowice 2016.

Hoffmann G.: Historia miasta Katowice. Tłum. D. Makselon, M. Skop. Katowice 2003.

Iwaszkiewicz J.: Podróże do Polski. Warszawa 1987.

Kostkiewiczowa T.: Palimpsest. W: Stownik terminów literackich. Red. J. Sławiński. Wrocław 1989.

Kozina I.: Chaos i uporządkowanie. Dylematy architektoniczne na przemystowym Górnym Ślasku w latach 1763-1955. Katowice 2005.

Lasiewicz-Sych A.: Obraz dialektyczny „,nowej” architektury. W: Przestrzeń, filozofia i architektura. Red. E. Rewers. Poznań 1999.

Lew and ow ski K.T.: Śląskie dziękczynienie. Wrocław 2009.

Lubrich F.: Katowickie Towarzystwo Śpiewacze im. Oskara Meistera. Tłum. M. Blidy. W: Katowice oczami Niemców i Polaków. Red. G.B. Szewczyk. Katowice 2017.

Marecki J., Rotter L.: Jak czytać wizerunki świętych. Kraków 2013.

Miuosh: Piąta strona świata. [Płyta CD]. Fandango Records 2011.

Nałęcz-Gostomski W.: Dzieje i rozwój Wielkich Katowic jako ośrodka przemystu i stolicy autonomicznego województwa śląskiego. Katowice 1926.

Netz F.: Dysharmonia caelestis. Katowice-Warszawa 2004.

Netz F.: W blasku ich śmierci. W: Idem: Trzy dni nieśmiertelności. Mikołów 2009.

Panofsky E.: Studia z historii sztuki. Wybrał, oprac. i posłowiem opatrzył J. Białostocki. Warszawa 1971.

Pruszyński K.: Węgiel i człowiek. „Wiadomości Literackie” 1936, nr 48.

Rutkowski H.: Studium gmachu cyrku wolnostojacego w Stalinogrodzie. Opis projektu. „Architektura" $1955, \mathrm{nr} 7$.

Sławek T.: Akro/nekro/polis: wyobrażenia miejskiej przestrzeni. W: Pisanie miasta. Czytanie miasta. Red. A. Zeidler-Januszewska. Poznań 1997.

Smolorz M. [S. Szulecki]: Cysorz. Katowice 1990.

Sobkiewicz L.: Waltera Benjamina filozofia ulicy. W: Przestrzeń, filozofia i architektura. Red. E. Rewers. Poznań 1999.

Szczypka-Gwiazda B.: Urbanistyka i architektura drugiej połowy XIX wieku i poczatku XX stulecia. W: Sztuka Górnego Ślaska. Red. E. Chojecka. Katowice 2004.

Szejnert M.: Czarny ogród. Kraków 2007.

Tuan Yi-Fu: Przestrzeń i miejsce. Tłum. A. Morawińska. Warszawa 1987. 
Ulice i place Katowic. Red. G. Grzegorek. Katowice 2015.

Waniek H.: Katowice blues. Katowice 2010.

Waniek H.: Wstep. W: Ulice i place Katowic. Red. G. Grzegorek. Katowice 2015.

Wisłocki S.A.: Janowscy, ,kapłani wiedzy tajemnej”. Okultyści, wizjonerzy i mistrzowie małej ojczyzny. Katowice 2013. 